\title{
Turkish foreign policy and the energy bonanza in the Eastern Mediterranean
}

\section{Hasan Selim Özertem}

To cite this article: Hasan Selim Özertem (2016) Turkish foreign policy and the energy bonanza in the Eastern Mediterranean , Journal of Balkan and Near Eastern Studies, 18:4, 361-374, DOI: 10.1080/19448953.2016.1195983

To link to this article: https://doi.org/10.1080/19448953.2016.1195983

曲 Published online: 20 Jul 2016.

Submit your article to this journal $\pi$

III Article views: 241

Q View related articles $₫$

View Crossmark data $[\pi$ 


\title{
Turkish foreign policy and the energy bonanza in the Eastern Mediterranean
}

\author{
Hasan Selim Özertem ${ }^{a, b}$

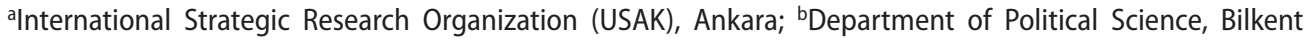 \\ University, Ankara
}

\begin{abstract}
This article examines the impacts on Turkish foreign policy of the recent discovery of energy deposits in the Eastern Mediterranean. Cyprus-dominated orientation of Turkish foreign policy in the Eastern Mediterranean has begun to change character as political and economic balances in the region have started to shift. While the discoveries of energy resources may have seemed to offer great opportunities at first, they have actually become a source of increasing contention due to existing unresolved conflicts and political disputes in the region. Turkey has found it especially difficult to keep up with the rapidly changing state of regional affairs as constraints on its technological capacity and political problems with old partners have come to weigh it down. In the end, the reactive nature of Turkey's approach to the developments in the region proved to have limited effect, and a new status quo is escaping its reach.
\end{abstract}

\section{Introduction}

The Eastern Mediterranean has long been an area of interest for Turkey's foreign policy elite due to the country's controversial history with the island nation of Cyprus. With the Cyprus Peace Operation of 1974, Turkey deployed troops to the island, thereby setting the foundations of its status as a guarantor state of what would nine years later come to be known as the Turkish Republic of Northern Cyprus (TRNC). In time, the hot conflict grew cold and what is now commonly referred to as the 'Cyprus issue' was granted a special place in Turkish foreign policy, ${ }^{1}$ as made evident by Turkey's maintenance of a military presence in the north of the island to this day. Nonetheless, with the discovery of what have been thought to be vast reserves of natural gas in the Eastern Mediterranean, discussions that once focused on the island's interior have changed shape as sovereignty claims are now being projected to the maritime areas of the island's exterior. In this regard, early steps that have been taken by the Greek Cypriot administration (the Republic of Cyprus) to exploit these resources, including the signing of agreements with private companies, have caused both Turkey and the TRNC to fear for their rights and interests in the Eastern Mediterranean. Put differently, the discovery of new hydrocarbon resources off the coasts of Cyprus has 
upped the economic stakes of an issue that had until then lain dormant, and therewith, the Eastern Mediterranean has once again become a region that is attracting the attention of not only Turkey, but also that of various other international heavy-hitters. ${ }^{2}$ The present state of affairs in the Eastern Mediterranean is now far beyond a simple dispute between Greek and Turkish Cypriots: it constitutes a paradigm shift that has once again propelled the Cyprus issue onto the international stage. Within this context, Turkey is not only hastening the activation of its hard power instruments in line with the principles of deterrence, but it is also trying to adopt new, comprehensive tools that can offset the balances which seem to be quickly shifting against its interests. Nonetheless, Turkey does not possess the technological capacity for offshore energy exploration and its room for political manoeuvre has gradually narrowed as a consequence of the rising tensions in its relations with Israel after 2010, with Syria after the outbreak of the civil war, and with Egypt after the fall of the Muslim Brotherhood. ${ }^{3}$ In the end, changing political balances in the Eastern Mediterranean resulting from political disputes and deepening instability in the region have had impacts on interstate relations, which in turn have also had crucial repercussions for energy politics. In this study, developments in the field of energy in the Eastern Mediterranean will be analysed within the scope of Turkish foreign policy. Interlinked with the new energy contest in the region, Turkey's exclusion from the demarcation of the Eastern Mediterranean's maritime borders has been perceived of as a threat to the country's sovereign rights. Considering the unresolved '12-mile' border dispute between Turkey and Greece in the Aegean, the rise of yet another maritime dispute, this time in the Eastern Mediterranean, brings with it new tests for Turkish foreign policy. Excluding the introduction and conclusion, the article is composed of two parts. First, I will scrutinize the developments regarding the exploration for hydrocarbons that has been taking place in the Eastern Mediterranean since the beginning of the 2000s. Second, I will focus on Turkey's reaction to recent developments in the Eastern Mediterranean, arguing that instead of trying to respond to these rapid changes in a reactive manner, Turkey needs to review proactively its relations with the littoral states in a constructive way. If this is not done, Turkey's policies may unintentionally provoke and solidify a new network of alliances that will stand in fundamental opposition to it interests in the region.

\section{Shifting partnerships amid the discovery of hydrocarbons in the Eastern Mediterranean}

Offshore hydrocarbon explorations in the Eastern Mediterranean have gained momentum over the last decade for several reasons. First of all, rising oil prices have made the cost of prospecting bearable for private companies. ${ }^{4}$ Second, the application of technological innovations such as horizontal drilling have further allowed for companies to engage in hydrocarbon exploration at lower costs. Lastly, and as a result of the first two reasons, once new energy reserves were discovered in the region, littoral states began to pursue more aggressive attempts at further exploration. In this regard, the discovery of substantial natural gas reserves off the coast of Gaza by British Gas (BG) in 1999 revitalized the decades-long defunct attempts at exploration of local and outside actors. ${ }^{5}$

According to estimates made by the US Geological Survey, there are 1.7 billion barrels of oil and 3.5 trillion $\mathrm{m}^{3}$ of natural gas beneath the seabed of the Eastern Mediterranean. ${ }^{6}$ As of today, the total combined volumes of all reserves discovered off the shores of Cyprus 
and Israel account for only 30-40 per cent of these estimations. The biggest breakthroughs in the discovery of hydrocarbons in the Eastern Mediterranean came at the end of the first decade of the 2000s. In 2009, Israel discovered a basin containing 235 billion $\mathrm{m}^{3}$ (bcm) of natural gas in the Tamar field off its coasts. Additionally, the country's discovery of yet another basin containing up to $450 \mathrm{bcm}$ of natural gas at the Leviathan field has been nothing but encouraging for upcoming projects in the area. These two fields occupy the top two spots on the list of the 10 largest deep-water gas reserves found between 2001 and 2010.7

These discoveries have also given reason for the Greek Cypriot administration to explore their own waters for energy resources, to which end they have put forth two calls for tender. The first of these calls was released in 2007 and American, Russian and Chinese firms expressed their interest in the project. Nonetheless, Turkey's vocal discontentment with the demarcation of Cyprus's southern maritime region into various blocs, in which the proposed explorations were expected to occur, ${ }^{8}$ and the continued political uncertainty on the island meant that only one medium-scale American firm, Noble Energy, would place a bid, and eventually come to win the tender. ${ }^{9}$ Noble Energy had been expressing its interest in the region for some time, which may be seen as natural considering that it was already involved in operations off the coast of Israel. However, drilling in bloc 12 (the Aphrodite field), off the southern coast of Cyprus, did not start until autumn 2011.

The second tender took place in 2012. Given the positive seismic readings in the Aphrodite field, five different companies and 10 joint ventures submitted a total of 15 different offers. After the bidding process, the Greek Cypriot administration awarded the consortium of Italian ENI and Korean Kogas licences to commence activity in blocks 2, 3 and 9, and TOTAL was awarded licences for blocks 10 and $11 .{ }^{10}$ Furthermore, starting in 2014, the Chinese energy company CNOOC has repeatedly expressed its interest in block 12. ${ }^{11}$ These international energy companies' recent activity off Cypriot shores shows how the dynamics have evolved to become increasingly complex half a decade after the discovery of previously latent energy resources. While the Greek Cypriot administration was only able to sign a single licensing agreement with a medium-scale company in 2007, now even the heavyweights are showing their willingness to take on not only the economic, but also political risks associated with commencing operations in the region. ${ }^{12}$

Apart from wooing the energy companies, Greek Cyprus has also pursued a proactive policy in the region that seeks to widen its political room for manoeuvre. In this sense, it has signed agreements with littoral states to delimit the economic exclusive zones (EEZs) of the Eastern Mediterranean, above and beyond the agreements it had already signed with Egypt and Lebanon in 2003 and 2007 respectively. ${ }^{13}$ The Lebanese Parliament has yet to ratify the agreement due to an ongoing dispute with Israel over its own maritime borders. It should be noted, however, that this delay in ratification is more closely related to the dispute with Israel than it is to any issues in Lebanese-Greek Cypriot relations as made evident by Speaker of the Parliament of Lebanon Nabih Berri's statement that his government will consider ratifying the agreement after resolving the dispute with Israel. ${ }^{14}$

While it can be seen that Greek Cyprus has been unable to come to a conclusive EEZ agreement with Lebanon, its negotiations with Israel have been much more fruitful as a result of recent developments in the region. Traditionally, the Greek Cypriot administration had been unsuccessful in delimiting its maritime borders with Israel because of the close relations between Tel Aviv and Ankara. Nonetheless, the Mavi Marmara Flotilla crisis in 2010 opened a window of opportunity for Greek Cyprus as Israeli-Turkish relations entered 
a phase of unprecedented tension. ${ }^{15}$ Up to this point, Tel Aviv had kept the Greek Cypriot administration's efforts to establish an EEZ in the Eastern Mediterranean at arm's length for fear of limiting its close ally's presence in the region, yet, when it was made clear that Israel's relations with Turkey would not be getting better, but on the contrary would dramatically worsen, Israel signed an EEZ agreement with Greek Cyprus in December 2010. ${ }^{16}$

The establishment of this EEZ agreement brought with it the added benefit of Israeli political support in the region, therefore allowing the Greek Cypriot administration to hasten its energy exploration efforts accordingly. It soon came to be seen that this new state of affairs was mutually advantageous for the parties, both economically and in terms of security. Economically, the parties started talks on developing natural gas reserves jointly; and in terms of the security, Israel, which had earlier been barred by Turkey from attending its military exercises known as Anatolian Eagle, started to carry out military drills with Greek Cyprus in the Eastern Mediterranean after the two signed a series of defence cooperation agreements in February 2012. ${ }^{17}$

Even though there are signs that Israel and Greek Cyprus have started to develop a special partnership, relations between the two may face limitations when it comes to cooperation in the energy sector due to their divergent interests. This has largely been the result of Israel's reluctance to become involved in a project that has so far not lived up to the country's interests. Here, the initial drilling results in the Aphrodite field were a disappointment for Greek Cyprus as the findings fell short of prior estimates. According to the assessments of seismic research, the field was predicted to contain gas reserves somewhere in the interval of 3.6-6 trillion cubic feet (tcf), yet initial drillings revealed a deposit of only $3.1 \mathrm{tcf}^{18}$ Even though these estimations were later revised to $4.74 \mathrm{tcf},{ }^{19}$ investors have still been wary of becoming involved in exploitation of the fields as a reserve that exhibits a volume of less than $5.5 \mathrm{tcf}$ would not be economically feasible when paired with the necessary construction of a Liquefied Natural Gas (LNG) facility on the island. ${ }^{20}$ This reality is compounded by the fact that declining oil prices make the development of these reserves even less attractive, as income achieved from the export of gas would be hard pressed to make up for the initial investment. Unless new deposits are found, one of the alternatives for Greek Cyprus is to call on its Israeli counterparts to form a consortium that could be tasked with constructing an LNG terminal in Vassilikos to market the gas. ${ }^{21}$ Yet, Israel seems to be losing interest in such an endeavour due to the high cost of the project. Thus, lower-cost solutions such as employing floating LNG technology, compressing the natural gas, or even using Egypt's infrastructure have been posed with increasing frequency recently. ${ }^{22}$

When it comes to drawing on Egyptian infrastructure, close interaction has been observed between BG, which operates LNG terminals on Egypt's Mediterranean coast, and the consortium active in the Leviathan field, which is composed of Delek, Noble Energy, Avner Oil and Ratio Oil. In this vein, the parties involved signed a non-binding agreement in June 2014 outlining that BG would receive $7 \mathrm{bcm}$ of natural gas per annum for 15 years. Furthermore, the consortium currently active in Israel's Tamar field signed a letter of intent in May 2014 with the Spanish company Union Fenosa to supply $71 \mathrm{bcm}$ gas to LNG terminals in Damietta, Egypt. ${ }^{23}$ Considering that companies aim to maximize their profits by commencing production as soon as possible with the best options available, the Leviathan consortium and BG have found it fitting to cooperate for the time being, an act that could come to reverse the character of Egyptian-Israeli bilateral relations. ${ }^{24}$ 
Until recently, Egypt was supplying Israel with natural gas before its supply lines were interrupted by attacks on the former's natural gas infrastructure, a side effect of the deepening instability and insecurity following the social movements that ultimately resulted in the fall of Hosni Mubarak. Now, however, there is a possibility that the roles will be reversed as Israel could begin to supply Egypt with gas, and thereby facilitate the formation of interdependence between the two countries. Furthermore, this possibility undermines, for the time being, the possibility of the northern alternative, namely, Israel cooperating with Turkey in the field of energy. In the past, potential collaboration in the energy sector between Turkey and Israel was discussed along with the possible participation of Cyprus, yet current geopolitical conjunctures have rendered these aspirations all but hopeless. Regardless, due to the current cap on gas exports outlined by Tel Aviv's regulations, ${ }^{25}$ if an agreement between companies in Israel and Egypt is successfully finalized, surplus gas left over for the northern route might not be enough to meet the pipeline's technical requirements. Nonetheless, there are still some prospects that keep the Turkish alternative on the table.

It is not unlikely that the sustainability of the Egyptian route may face certain constraints in terms of security as well as capacity in the future and this may leave the Turkish route open for Israeli gas in economic terms. After the discovery of vast natural gas reserves by ENI in the Zohr field off Egypt, Israel's Energy Minister Yuval Steinitz said that 'the discovery of the Egyptian gas field is a painful reminder that while Israel has been asleep at the wheel and delaying final approval of the gas deal and additional exploration, the world is changing before our very eyes with implications for export possibilities. ${ }^{26}$ In fact, the possibility of increasing natural gas production in Egypt and maintaining the supply of Israeli gas at the same time might face some difficulties to manage, but does not overrule possible cooperation. Nonetheless, even under these circumstances if Israel and Egypt agree on a trade deal Israel would still be able to export a substantial amount of gas to both Egypt and Turkey, with the condition that the Tamar and Leviathan consortiums manage to convince the government in Tel Aviv to increase the export cap in return for them ensuring that smaller deposits would be set aside for the use of future generations. Keeping this in mind, Turkish companies continue to actively advocate the transport of Israeli gas to Turkey via a pipeline from the Leviathan field. ${ }^{27}$ Yet, the tense state of Turkish-Israeli relations still stands as a significant barrier to such endeavours and, furthermore, it amplifies the political risk in calculations that are made before investment in such projects is decided upon. ${ }^{28}$

\section{Turkey's approach: reactive rather than proactive}

As new partnerships take form in the region and international energy companies engage in drilling operations off the shores of Cyprus, Turkey is struggling to develop new policies that can tackle the rising challenges. While inherently linked with the unresolved conflict on the island, these challenges are also closely related to the changing status quo on the high seas of the Eastern Mediterranean, as the partitioning and exploitation of the region's resources without Turkey's input directly affects the country's sovereign interests as a littoral state. By the same token, the newly discovered natural gas reserves are strategically and economically attractive to Turkey's domestic market, and could even help the country to contribute to European energy security, thus adding another layer to the complex geopolitical dynamic taking shape. Within this context, Turkey has employed a number of tactics to increase its say with regard to the hydrocarbon discoveries offshore from Cyprus and Israel. In this 
section of the article, Turkey's policies vis-à-vis the recent energy bonanza in the Eastern Mediterranean will be analysed. The discovery of these new reserves has had three primary implications for Turkish foreign policy. First, Turkey has been forced to try to adopt new instruments to balance the steps already taken by Greek Cyprus. Second, while the Turkish route is the most feasible for Israeli gas, the political tension between Ankara and Tel Aviv is a significant obstacle to the realization of this option.

As discussed already, Israel's discovery of new reserves is a breakthrough for the region. However, exploitation of the Greek Cypriot Aphrodite field remains, for the time being, economically infeasible. Moreover, the results of the second round of drilling by ENI and Kogas came up with dry wells and TOTAL failed to find any promising reserves to begin drilling, ${ }^{29}$ but a $30 \mathrm{tcf}$ natural gas discovery off the coast of Egypt might represent an important incentive to continue exploration off the coast of Cyprus. Throughout this process, Turkey has remained hesitant about the ongoing unilateral steps taken by Greek Cyprus based on three primary concerns. First, the EEZ agreements that Greek Cyprus has signed with littoral states in the region act to harm Turkish interests in the Eastern Mediterranean. ${ }^{30}$ Second, Greeks on the island claim that the administration in the south represents the entirety of the island, and that it therefore has the sovereign right to make agreements with foreign firms. However, due to the de facto division of the island, a problem arises when it comes to the sharing of potential revenues to be gained from the natural gas deposits. Third, if Greek Cyprus does find new reserves off its coasts, a further change to the existing paradigm could erect new obstacles to finding a solution to the Cyprus issue at large. ${ }^{31}$ Here, even though the likelihood of coming to a resolution on the island fell markedly after the accession of the Republic of Cyprus to the EU, this worry is not without grounds.

These three concerns are pushing Turkey to develop new policies that mobilize the country's diplomatic, security and economic instruments. Yet, up to this point these policies have mainly been reactive, as they aim to balance and counter the moves of Greek Cyprus in the Mediterranean after they have already been made. These policies are also defensive, as they aim to preserve Turkey's sovereign rights as well as the status quo on the island until a permanent diplomatic solution is reached. In other words, these policies are mainly designed to preserve the existing order rather than embrace the changes that have materialized as a consequence of the decisions made by Turkey's counterparts.

In this context, following Noble Energy's decision to start drilling in the Aphrodite field, Turkey and the TRNC signed a continental shelf agreement in New York on 21 September 2011. ${ }^{32}$ Moreover, the TRNC issued Turkey's state-owned energy firm the Turkish Petroleum Corporation (TPAO) with licences for on- and offshore drilling. ${ }^{33}$ However, the blocs covered by these licences overlap with seven out of the overall 13 blocs already claimed by Greek Cyprus, namely, blocs 1, 2, 3, 8, 9, 12 and 13. Additionally, Turkey claims partial rights to blocs 1, 4, 5, 6 and 7. Ultimately this has resulted in Turkey, together with the TRNC, enacting blockades on 11 of the 13 blocs that are claimed by Greek Cyprus in the south of the island.

This decision to claim sovereign rights over a wide maritime space in coordination with the TRNC is an unprecedented occurrence in Turkey's Mediterranean policy. Consequently, the characteristics of the Cyprus issue, which was until this point deemed to be a 'frozen' conflict, have changed as the delimitation of maritime borders has now been added to the inland territorial dispute. 
Compared with Greek Cyprus, Turkey has tended to follow a more conservative attitude in the Mediterranean and Aegean. Yet now, Greek Cyprus's proactive policy in the region has in turn prompted Turkey to become more aggressive in its own attempts to seek potential hydrocarbon reserves in the Mediterranean. Here, Turkey has come to draw on its experience in prospecting for energy resources in the Black Sea. As allowed by Turkey's 1986 EEZ in the Black Sea, international companies such as Petrobras, Exxon and Chevron cooperated with TPAO in drilling wells on Turkey's Black Sea coasts parallel to the international fad of searching for offshore reserves in the 2000s. Looking at the structure of these consortiums, technological input and experience in offshore drilling is usually provided by the international energy companies, and in this sense TPAO has the advantage of having actively carried out operations with such firms. Nonetheless, despite its experience, TPAO still lacks the necessary equipment for offshore operations.

After the drilling of three offshore wells on the coasts of Mersin and the Gulf of Iskenderun in 1970, the Mediterranean has not seen any serious activity undertaken by the TPAO. ${ }^{34}$ It can be seen that it is not the economic dimension of hydrocarbon exploration that has come to shape Turkey's policy in the region, but rather the uncertain legal status of Cyprus. Nonetheless, Ankara's recent assumption of a hard-line stance has started to signal a change in its formerly reluctant attitude. The signing of the aforementioned continental shelf agreement with the TRNC and the establishment of a deal with Shell to explore the prospects of energy resources off the coast of Turkey's southern city of Antalya are both examples of the change in Ankara's approach to the topic. ${ }^{35}$

Even though Turkey no longer seems to fear stepping on anyone's toes in the Mediterranean post-2011, its insufficient technological capabilities have made it difficult for the country to actively commence offshore drilling itself. Here, Turkey's supposedly decisive response to Noble Energy's decision to drill in the Aphrodite field was the deployment of a 34-year-old research vessel, the Piri Reis, to the region for seismographic surveying. Understandably, the 2D seismic technology of this vessel that was built in 1978 was harshly criticized for being way too out of date to carry out any form of comprehensive or conclusive research. In response, Turkey announced its intentions to develop a modern vessel worth $€ 100$ million that was capable of 3D seismography surveying, and in 2013 a seismographic research vessel was bought from the Norwegian company Polarcus, and named after Barbaros Hayreddin Pasha who established the Ottoman supremacy in the Mediterranean in the sixteenth century. ${ }^{36}$ The vessel then went on to carry out seismographic surveying in the Mediterranean throughout the rest of the year. ${ }^{37}$

Despite the construction of the advanced research vessel, TPAO still does not have an offshore platform in its inventory. ${ }^{38}$ Consequently, the inadequacy of Turkey's national energy champion has also shaped the ways in which the country has taken steps retaliatory to the Greek Cypriot administration's activity in the region. Due to its limited resources, TPAO started drilling an onshore well near the town of İskele (Trikomo) in the TRNC in April 2012. ${ }^{39}$ This move struck a chord as the disturbed Greek Cypriot administration began to voice harsh criticism of the TPAO's operations, accusing both Turkey and the Turkish Cypriot leadership of violating international law by going ahead with drilling. ${ }^{40}$

Turkey's ongoing balancing policy shows that it still sees the issue through the prism of sovereignty and its status as a guarantor state of the northern portion of the island. In this vein, adopting a reciprocal policy by using its own (limited) energy operations as leverage, Turkey also sent gunboats to the region as part of its traditional policy. ${ }^{41}$ While using 
corvettes as an instrument of deterrence in the region caused concerns in the south, it did not result in hot conflict and it did not obstruct the drilling activities of Noble Energy in the Aphrodite field in 2012 or those of the ENI-Kogas consortium in 2014. It was, however, used by the Greek Cypriot administration as an excuse to terminate peace negotiations on the island. In October 2014, as Turkey's Barbaros Hayreddin Pasha, accompanied by Turkish military vessels, entered the disputed waters of bloc 9 where ENI-Kogas aimed to start drilling, the Greek Cypriot administration stormed out of peace negotiations that began in February of that year. ${ }^{42}$

Although Turkey does not officially recognize the Republic of Cyprus, the fact that it enjoys legitimate representation in the international arena facilitates widespread support for its advances. The Greek Cypriot administration asserts that it is pursuing policies as the sole sovereign power of the island, an assertion that is also being used to its advantage in negotiations with international companies. In this respect, it goes without question that Greek Cyprus also has no difficulties in securing the support of the EU and the US. In the Turkey 2012 Progress Report, referring to the Cyprus issue, 'the EU stressed the sovereign rights of EU Member States which include, inter alia, entering into bilateral agreements, and to explore and exploit their natural resources in accordance with the EU acquis and international law, including the UN Convention on the Law of the Sea. ${ }^{43}$ A similar emphasis can be found in the 2013 and 2014 progress reports as well. ${ }^{44}$ The US also highlights that 'the Republic of Cyprus has the right to develop the resources in its internationally recognized Exclusive Economic Zone. ${ }^{45}$

Moreover, for the US, this unease has implications for the greater region. In this sense, Washington, DC is eager to find a solution to the Cyprus conflict as well as the dispute between Tel Aviv and Ankara as the resultant tumult 'limit[s] the effectiveness of a U.S. policy response to the Arab uprisings. ${ }^{46}$ For this purpose, US Vice-President Joe Biden visited the island in May 2014 stating that 'the U.S. is prepared to provide any assistance in Cyprus reunification talks', adding that 'it's possible to reach a settlement for a reunited Cyprus as a bi-zonal, bi-communal federation'. ${ }^{47}$ Indeed, the US and EU share a common interest in facilitating the development of Eastern Mediterranean hydrocarbon resources as this would bolster the security of Europe's energy supply and contribute to the stability and peace building in the region. The recent Russia-Ukraine crisis has further strengthened this ambition as the parties look for ways to feed the Southern Corridor that would bring extra gas to the European market.

The problematic state of Cyprus's peace negotiation process supplemented by the political crisis that has emerged between Israel and Turkey further serves to inhibit the materialization of an atmosphere in which fruitful dialogue can take place among the littoral states of the Eastern Mediterranean. Israel's operations in Gaza in the summer of 2014 have further contributed to this downward trend, as made evident by the statement of Turkish Minister of Energy and Natural Resources, Taner Yildiz, that 'it is out of the question to proceed on any energy project unless a permanent peace is established [in Gaza], with contribution from all sides and with the necessary conditions. ${ }^{48}$ Here, although the Turkish route is seen as the most economically feasible option for Israeli gas and seeing that it would offer the additional political benefit of generating a new paradigm of cooperation, the path to cooperation is fraught with difficulties.

The dim prospects for cooperation envisioned by the northern, Turkish route and recent geopolitical shifts allow other alternatives, in which Turkey is not included, to gain ground, 
such as in the cases of the Egypt-Greece-Cyprus rapprochement and the Egypt-Israel dialogue on marketing gas via LNG facilities in Egypt. Meeting in Cairo, Abdel Fattah al-Sisi, Nicos Anastasiadis and Antonis Samaras signed a declaration in November 2014 in which they supported the Greek Cypriots' claims of sovereign rights in the Eastern Mediterranean and agreed to speed up the negotiations on the delimitation of their maritime borders. ${ }^{49} \mathrm{~A}$ second summit took place in April 2015, this time in Nicosia, during which time the parties reasserted their commitment to proceed with the negotiations on maritime delimitation in the Mediterranean. ${ }^{50}$

In the case of the Egypt-Israel dialogue, regime change in Egypt and the fall of Mohammed al-Morsi have added to the attractiveness of the Egyptian option for Israel. As a result, the idea of the northern, Turkish route for the Eastern Mediterranean gas, which could also be an important input in Turkey's consumption portfolio over the next decade, is gradually losing momentum due to the political tension between Ankara and Tel Aviv. In fact, the growth in cooperation between Israel and Egypt in the field of energy is not merely an economic phenomenon, but also has political implications that may manifest themselves in the form of greater interdependence between the two countries. ${ }^{51}$ Additionally, idle terminals in Egypt are attractive for Israeli consortiums, as BG and Fenosa pressure Cairo to import Israeli gas so that their own investment costs will be dramatically reduced. Still, compared with the potential of the gas market in Turkey (and also Europe via Turkey), the Egyptian alternative is less attractive in economic terms. Moreover, discovery of the Zohr gas field also brings up further questions about the feasibility of the Egyptian route for the Israeli gas.

\section{Conclusion}

In conventional terms, the Cyprus issue has long occupied the bulk of Turkey's focus in the Eastern Mediterranean. However, with the changing balances resulting from tectonic shifts in the geopolitics of the Middle East after the US invasion of Iraq and the Arab uprisings, Turkey has been forced to concentrate on the developments in the region more than ever. While trying to adapt to the new balances, Turkey has become more and more enmeshed in the region's disputes at a time that coincides with the discovery of new energy deposits in the Eastern Mediterranean. Having an extensive Mediterranean coastline and access to the European energy market, one would think that Turkey could be able to take advantage of these discoveries in terms of resource exploration and eventual marketing. Nonetheless, geopolitical constraints and technological limitations have put Ankara in a position in which it can merely react in a defensive manner rather than pursue proactive diplomacy.

So far, the main challenge for Turkey has been posed by Greek Cyprus's efforts to sign EEZs with littoral states in the 2000s, thus carrying the discussions over the future of the island's inland territory to the high seas. Turkey had practised restraint when it came to hydrocarbon exploration in the Mediterranean until this point, choosing to preserve the status quo in the region due to the unresolved status of the Cyprus issue. Yet, by pursuing active diplomacy that took advantage of the changing balances, the Greek Cypriot administration even succeeded in signing an agreement with Turkey's long-term ally, Israel, in 2010. The deterioration in Turkish-Israeli relations was a significant cause of the change in Tel Aviv's position, as it had previously avoided forming close relations with Greek Cyprus. Moreover, this turn of events has also had soaring implications for the routes through which Israeli gas will be introduced to the international market. Turkey represents the most feasible route 
and the fact that it hosts a dynamic economy also makes it a good destination for Eastern Mediterranean gas. Nevertheless, ongoing political tension between these two countries is seen as a risk that impedes the possibility of such a partnership.

Initially, Turkey adopted its traditional deterrence diplomacy to halt the activities of oil companies off the shores of Cyprus. Nonetheless, this tactic fell short of maintaining the status quo on the island and instead forced Turkey to employ other instruments in a more reciprocal manner. Signing a continental shelf agreement with the TRNC, and constructing a state-of-the-art research vessel, Turkey strove to keep up with the developments by joining in the resource exploration bonanza. Yet, its technological incapacity pushed it to invest more in the offshore drilling capacities of its national energy giant. The steps taken by the Greek Cypriots and the Turks have also negatively affected the peace negotiation process on the island by escalating tensions and generating new barriers to diplomatic efforts.

Ultimately, the recent discovery of energy deposits in the Eastern Mediterranean is not merely an economic phenomenon. It poses crucial opportunities for peace and stability in the region. Nonetheless, the current political dynamics bring with them a host of new challenges for the littoral states. In this regard, Turkey is no exception as it tries to keep its head above water in the rapidly changing environment. For now, it seems that Turkey's reactive efforts fall short of affecting the newly crystallizing political and security balances in the region. Sooner rather than later, Turkey needs to make certain decisions regarding its policies towards the Eastern Mediterranean. Its gunboat diplomacy has its own risks that may result in unintended consequences, and its economic instruments, particularly in the offshore contest, are limited. Under these circumstances Turkey has two main alternative policies that it could follow. On the one hand, Turkey could continue its policy of escalation; but this approach will likely backfire as it will bring the country's capacity deficit under increased scrutiny and bring Egypt, the Greek Cypriot administration and Israel (and probably Greece) closer in the process. On the other hand, Ankara could look for possibilities to normalize its relations with at least some of its neighbours. This would allow Turkey to foster cooperation and undermine the current trend that is deepening its isolation in the region. Turkey must realize that the earlier status quo of the region is gone and that trying to force its return will only make things worse.

\section{Disclosure statement}

No potential conflict of interest was reported by the author.

\section{Notes on contributor}

Engaged in research at USAK since 2006, Hasan Selim Özertem became the Director of the organization's Center for Security and Energy Studies in 2016. As a comparative political scientist, Özertem has focused the majority of his research on security, energy, elite politics, Eurasia, and Turkish Foreign Policy. He was a visiting scholar at the Carnegie Moscow Center from April to July 2013 and is also the co-editor of the academic journal Review of International Law and Politics. Before beginning his doctoral studies at Bilkent University's Department of Political Science, Özertem obtained a Master's Degree in Eurasian Studies from the Middle East Technical University, and a Bachelor's Degree in Economics from the same university in Ankara. 


\section{Notes}

1. Baskın Oran, ed., Türk Dış Politikası Vols I-II [Turkish foreign policy], İletişim, Ankara, 2004; Mustafa Aydin, 'Determinants of Turkish foreign policy: changing patterns and conjunctures during the cold war', Middle Eastern Studies, 36(1), 2000, pp. 103-139; Kıvanç Ulusoy, Doğu Akdeniz'de Güç Mücadelesi ve Kıbrıs Sorunu [Power Struggle in the Eastern Mediterranean and the Cyprus Issue], USAK Yayınları, Ankara, 2015.

2. Volkan Ş. Ediger, Balkan Devlen and Deniz Bingöl Mcdonald, 'Levant'ta Büyük Oyun: Doğu Akdeniz' in Enerji Jeopolitiği' [The great game in the Levant: energy geopolitics in the Eastern Mediterranean], Uluslararası İlişkiler, 9(33), 2012, pp. 73-92.

3. Ziya Öniş, 'Turkey and the Arab revolutions: boundaries of regional power influence in a turbulent Middle East', Mediterranean Politics, 19(2), 2014, pp. 203-219.

4. The price of oil steadily increased in the 2000s until the financial crisis in 2008. After a dramatic decline in 2009, the average price of oil was later fixed at between 90 and 110 dollars per barrel. This price level posed a favourable basis for taking on the risk of high-cost offshore operations.

5. BG found a reserve containing $1 \mathrm{tcf}$ of gas in the Marine- 1 field. This was seen as an opportunity for economic cooperation between Israel and the Palestinian Authority but could not be realized due to political disputes. For further information, please refer to Anais Antreasyan, 'Gas finds in the Eastern Mediterranean: Gaza, Israel and other vonflicts', Journal of Palestine Studies, 42(3), 2013, pp. 29-47; Walid Khadduri, 'East Mediterranean gas: opportunities and challenges', Mediterranean Politics, 17(1), 2012, pp. 111-117.

6. USGS, Assessment of Undiscovered Oil and Gas resources of the Levant Basin province, Eastern Mediterranean, 8 April 2010, <http://pubs.usgs.gov/fs/2010/3014/pdf/FS10-3014. pdf $>$ (accessed 28 November 2012).

7. Sohbet Karbuz, 'East Mediterranean Energy policy: cooperation or conflict', Seminar presented at the International Strategic Research Organization (USAK) Conference, 26 July 2012.

8. John C. K. Daly, 'Energy exploration issues threaten Turkey's EU prospects', Eurasia Daily Monitor, 4(44), 5 March 2007, <http://www.jamestown.org/single/?no_cache=1\&tx_ ttnews\%5Btt_news\%5D=32551> (accessed 27 November 2014).

9. Andreas Philippou, 'Cyprus Gas Exploration Opportunities', Baker Tilly Klitou, March 2012, <http://www.bakertillyklitou.com/uploadfiles/Articles/Cyprus_gas_exploration_ opportunities_APH_Mar12.pdf> (accessed 26 November 2014); Anastasios Giamouridis, 'The Offshore Discovery in the Republic of Cyprus: Monetisation, Prospects and Challenges', Oxford Institute for Energy Studies, July $2012<$ https://www.oxfordenergy.org/wpcms/wpcontent/uploads/2012/07/NG_65.pdf> (accessed 26 November 2014).

10. Catherine Hunter, 'Exploration licenses awarded to Eni/Kogas, Cyprus books upfront bonuses', IHS Global Insight Daily Analysis, 25 January 2013 <https://www.ihs.com>; Gary Lakes, 'Cyprus Calls Time on More License Awards', Platts, 1 February $2013<$ http://www. platts.com>; 'Cyprus signs offshore deal with Total, puts hope in hydrocarbons', Reuters, 6 February 2013 < http://www.reuters.com/article/2013/02/06/cyprus-hydrocarbons-idUSL5N0B678720130206> (accessed 18 October 2014).

11. 'China Oil in talks to buy part of Aphrodite Field (updated)', Cyprus Mail, 19 June 2013, $<$ http://cyprus-mail.com/2014/06/19/china-oil-in-talks-to-buy-part-of-aphrodite-field/> (accessed 18 October 2014).

12. Turkey warned that energy companies that signed agreements with the Greek Cypriot administration would be disqualified from new energy projects in Turkey. For further information please refer to 'Türkiye'den G. Kıbrıs'la Ortak Petrol Arayana Uyarı' [Turkey warns companies that explore oil with Greek Cypriots], Sabah, 4 November 2012; 'Türkiye, Güney Kıbrıs'ta Petrol Arayan Şirketleri Uyardı' [Turkey warned companies exploring oil in Southern Cyprus], Zaman, 3 November 2012.

13. For full text of the agreement between Egypt and the Greek Cypriot administration please refer to 'the Agreement between the Republic of Cyprus and the Arab Republic of Egypt on the delimitation of the exclusive economic zone of 17 February 2003', <http://www.un.org/ 
depts/los/LEGISLATIONANDTREATIES/PDFFILES/TREATIES/EGY-CYP2003EZ.pdf> (accessed 23 September 2014); Lebanese Minister of Foreign Affairs and Emigrants Adnan Mansour sent a letter to the Secretary General of the UN that objected to the delimitation of the EEZ between Israel and Cyprus in 2011. For the full text please refer to $<$ http://www. un.org/depts/los/LEGISLATIONANDTREATIES/PDFFILES/communications/lbn_re_cyp_ isr_agreement2010.pdf> (accessed 23 September 2014).

14. 'Lebanon to Ratify Agreement with Cyprus Once dispute with Israel Ends', The Daily Star, 1 March 2012, <http://www.dailystar.com.lb/News/Politics/2012/Mar-01/165157-cyprus-vowssupport-for-lebanon.ashx\#ixzz3FOfBIh3G> (accessed 6 October 2014).

15. Hasan Kosebalaban, 'The Crisis in Turkish-Israeli Relations: what is its strategic significance?, Middle East Policy, 17(3), 2010. pp. 36-50.

16. 'Israel-Cyprus exclusive economic zone set', Ynetnews, 19 December 2010, <http://www. ynetnews.com/articles/0,7340,L-4000679,00.html> (accessed 18 October 2014).

17. Konstantinos J. Hazakis and Michalis Chailis, 'The role of economic diplomacy on energy projects: the exploration of natural gas resources at Cyprus Exclusive Economic Zone, International Journal of Diplomacy and Economy, 1(3/4), 2013, pp. 291-308; 'Cyprus and Israel mount joint military exercise', Cyprus Mail, 11 February 2014; <http://cyprus-mail. com/2014/02/11/cyprus-and-israel-mount-joint-military-exercise/> (accessed 6 October 2014).

18. Elias Hazou, 'Gas prospecting to be speeded up', Cyprus Mail, 1 April 2014, <http://cyprusmail.com/2014/04/01/gas-prospecting-to-be-speeded-up/\#prettyPhoto $>$ (accessed 7 October 2014).

19. 'Firms developing Cyprus gas field raise reserve estimate 12 pct', Reuters, 18 November 2014; < http://www.reuters.com/article/2014/11/18/delek-group-noble-energy-cyprus-idUSL6 N0T83UJ20141118> (accessed 15 January 2015).

20. Constantine Levoyannis and Mathieu Labrèche, 'New gas discoveries in southern periphery may transform European energy landscape', Energy Post, 13 December 2013, <http://www. energypost.eu/new-gas-discoveries-europes-southern-periphery-may-transform-europeanenergy-landscape/> (accessed 6 October 2014).

21. 'Vassilikos LNG terminal construction negotiations reach final stages', Natural Gas Europe, 12 August 2013, <http://www.naturalgaseurope.com/cyprus-vassilikos-lng-terminal> (accessed 6 October 2014).

22. Elias Hazou, 'Talks aim at agreement of LNG terminal', Cyprus Mail, 24 August 2014, <http:// cyprus-mail.com/2014/08/24/talks-aim-at-agreement-of-lng-terminal/> (accessed 7 October 2014); interview with Dr Alon Liel, Former Israeli Ambassador to Ankara, 7 May 2014.

23. Sharon Udasin, 'British Gas Group mulling Leviathan gas for Egyptian LNG plant', JPOST, 29 June 2014, <http://www.jpost.com/Business/Business-Features/British-Gas-Group-mullingLeviathan-gas-for-Egyptian-LNG-plant-360956> (accessed 18 October 2014).

24. Keith Johnson, 'Israel's Leviathan captures another gas deal', Foreign Policy, 3 September 2014, $<$ http://www.foreignpolicy.com/articles/2014/09/03/israels_leviathan_captures_another_gas_ deal_noble_jordan $>$ (accessed 18 October 2014).

25. Tel Aviv has put a 40 per cent ceiling on the gas exports from its Leviathan and Tamar fields.

26. Joel Greenberg and Tamer El-Ghobashy, 'Israeli officials concerned about gas discovery in Egypt', Wall Street Journal, 2 September 2015, <http://www.wsj.com/articles/israeli-officialsconcerned-over-gas-discovery-in-egypt-1441233087> (accessed 21 September 2015).

27. Ali Ünal, 'Pipeline for Israeli gas on the table', Daily Sabah, 15 May 2014.

28. Alon Liel and Amit Mor, 'Israeli gas exports as a vehicle for enhancing regional cooperation', Palestine-Israel Journal, 19(4) and 20(1), 2014, p. 20.

29. These companies also could not find exploitable reserves after their initial drillings offshore of the island, but they are assessing the data collected for further explorations. 'Eni, KOGAS find no exploitable hydrocarbons off Cyprus', Reuters, 26 March 2015, <http://in.reuters. com/article/2015/03/26/cyprus-natgas-eni-idINL6N0WS3M420150326> (accessed on 11 May 2015). 
30. Cenk Özgen, 'Doğu Akdeniz'de Enerji Güvenliğine Yönelik Bir Girişim: Akdeniz Kalkanı Harekâtı' [An initiative to energy security in the Eastern Mediterranean: Operation Mediterranean Shield], Akademik Ortadoğu, 8(1), 2013.

31. Erdogan also accused the Greek Cypriots of sabotaging peace in the region following the decision to commence drilling in the Aphrodite field: 'Erdoğan: Ciğerim Yanıyor Ciğerim' [Erdogan: I suffer great hardship], Radikal, 28 September 2011.

32. Press Statement on the Continental Shelf Delimitation Agreement Signed between Turkey and the TRNC, No. 216, 21 September 2011, <http://www.mfa.gov.tr/no_-216_-21-september2011_-press-statement-on-the-continental-shelf-delimitation-agreement-signed-betweenturkey-and-the-trnc.en.mfa $>$ (accessed 18 October 2014).

33. 'KKTC'den TPAO Kararı' [TRNC's decision on TPAO], Sabah, 22 September 2011; 'TPAO ile KKTC Protokol İmzaladı' [TRNC and TPAO inked a protocol], Haberturk, 2 November 2011.

34. TPAO, 'Derin Deniz Arama Projeleri' [Offshore projects]; <http://www.tpao.gov.tr/ $\mathrm{tp} 5 /$ ? $\mathrm{tp}=\mathrm{m} \& \mathrm{rid}=27>($ accessed 12 October 2014$)$.

35. Orhan Coskun, 'UPDATE 1-Turkey's TPAO, Shell sign exploration deal', Reuters, 23 November 2011, <http://www.reuters.com/article/2011/11/23/turkey-shell-idUSL5E7 MN1AA20111123> (accessed 19 October 2014).

36. "Barbaros Hayrettin Paşa" Geldi' ["Barbaros Hayreddin Paşa” arrived], NTVMSNBC, 31 January 2013, <http://www.ntvmsnbc.com/id/25418325> (accessed 13 October 2014).

37. 'Barbaros Hayreddin Sondaj İçin Akdeniz'de' [Barbaros Hayreddin is in Mediterranean for drilling], Sabah, 4 September 2014.

38. Response of Minister of Energy Taner Yild1z to written parliamentary inquiry No. B. 15.0.SGB.02619-157 by Member of Parliament Gürkut Acar on 19 October 2011.

39. 'Doğalgaz İçin Tarihi Gün' [Historical day for natural gas], Vatan, 26 April 2012.

40. 'Protest as Turkey drills for oil in Northern Cyprus', BBC News, 26 April 2012, <http://www. bbc.com/news/world-europe-17852182> (accessed on 13 October 2014).

41. Igor Delanoe, 'Cyprus, a Russian foothold in the changing Eastern Mediterranean', Middle East, 17(2), p. 90; Aphrodite's Gift: Can Cypriot Gas Power a New Dialogue?, Europe Report No. 216, 2 April 2012.

42. Alkman Granitsas, 'Cyprus, Turkey braced for new fight over gas reserves', Wall Street Journal, 10 October 2014.

43. EU Commission Staff Working Document Turkey 2012 Progress Report, Brussels, 10 October 2012, p. 36.

44. EU Commission Staff Working Document Turkey 2014 Progress Report, Brussels, 16 October 2013, p. 17; EU Commission Staff Working Document Turkey 2014 Progress Report, Brussels, 8 October 2014, p. 19.

45. Remarks by US Ambassador John M. Koenig, 'Hydrocarbons and sustainable development in Cyprus and the Eastern Mediterranean region', German Marshall Fund Workshop, 25 September 2013, <http://cyprus.usembassy.gov/sp-amb_marshall_fund_sep13.html> (accessed 19 January 2015).

46. Ioannis N. Grigoriadis, 'Energy discoveries in the Eastern Mediterranean: conflict or cooperation?', Middle East Policy, 21(3), 2014, p. 131.

47. Marcus Bensasson and Georgios Georgiou, 'Biden hails Cyprus as key new player in global gas industry', Bloomberg, 22 May 2014, <http://www.bloomberg.com/news/articles/2014-05-22/ biden-meets-cyprus-president-anastasiades-with-energy-on-agenda $>$ (accessed 22 December 2015).

48. Murat Tinas, 'Turkey closes its doors to Israeli gas', Natural Gas Europe, 6 August 2014, <http:// www.naturalgaseurope.com/turkey-closes-its-doors-for-israeli-gas-for-now $>$ (accessed 19 September 2014).

Orhan Coskun, 'Turkey snubs possible energy deals with Israel After Gaza Offensive', Reuters, 9 September 2014, <http://www.reuters.com/article/2014/09/09/us-mideast-gazaturkey-israel-idUSKBN0H41G520140909> (accessed 19 September 2014).

49. 'Cyprus, Greece, Egypt sign Cairo declaration', BBC, 10 November 2014. 
50. 'Cyprus, Greece and Egypt to proceed expeditiously with maritime zones' delimitation', Cyprus News Agency, 29 April 2015.

51. The pipeline carrying gas to Israel from Egypt has been attacked several times and the sustainability of this transmission has become difficult due to political turmoil in Egypt. But an offshore link of gas supply in the opposite direction may open new windows of opportunity for further cooperation. For further information please refer to Gawdat Bahgat, 'Egypt's energy outlook: opportunities and challenges', Mediterranean Politics, 24(1), 2014, p. 21. 